\title{
Comparative evaluation of ondansetron and granisetron in prevention of postoperative nausea and vomiting following laparoscopic cholecystectomy in females
}

\author{
Mohamad Ommid ${ }^{1}$, Mubasher Ahmad ${ }^{2}$, Nusrat Jehan ${ }^{3}$, Faisal Ismail Shiekh ${ }^{4}$, \\ Sheeba Nazir ${ }^{5} \&$ Gousia Nissa \\ ${ }^{1,3}$ (Lecturer Anesthesiology\& Critical care, GMC \& Associated Hospitals SMHS, Srinagar, India) \\ ${ }^{2}$ (Senior Resident Anesthesiology \& Critical care, SKIMS, Srinagar, India) \\ ${ }^{4}$ (Assistant Consultant, Department of Anaesthesiology K.F.M.C, Riyadh, K.S.A ) \\ ${ }^{5,6}$ (Medical officer, $J \& K$ Health services, India)
}

\begin{abstract}
Post operative nausea and vomiting (PONV) continue to be frequent occurrences, even when conventional antiemetics are prophylactically used. In a randomized double blind study, 100 female patients scheduled for elective laparoscopic cholecystectomy under general anaesthesia were divided into 2 groups of 50 patients each and received $0.1 \mathrm{mg} / \mathrm{Kg}$ of Ondansetron (Group X) or $0.04 \mathrm{mg} / \mathrm{Kg}$ of Granisetron (Group Y) preoperatively. Patients were observed for 24 hours post operatively and interpretation of symptoms of nausea and vomiting was done according to Gan and Alexander scale (0-2). $80 \%$ of patients in Group Y and $48 \%$ patients in Group X did not experience PONV; the difference was statistically significant ( $p<0.001) .2$ patients $(4 \%)$ in Group $Y$ and 15patients (30\%) in Group $X$ required rescue antiemetic medication during the 24 hour study period. The difference was found to be highly significant $(p<0.001)$ The difference in the incidence of PONV between the two groups after 6 hours to 24 hours was highly significant $(p<0.001)$. It was concluded that prophylactic administration of Granisetron is more effective than Ondansetron, in reducing in incidence of $P O N V$ with prolonged effects.
\end{abstract}

Key words: Granisetron, laparoscopic cholecystectomy, Ondansetron,

\section{Introduction}

Postoperative nausea and vomiting (PONV) remains one of the most common complications related to surgery and anaesthesia. Referred to as the "big little problem", its complications range from minor patient discomfort to gastric aspiration. Postoperative nausea and vomiting (PONV) can occur after general, regional or local anaesthesia. ${ }^{[1]}$ An overall estimate of PONV is approximately $20-30 \%$ of all adult surgical patients. ${ }^{[2]}$ Most investigators have reported a significantly higher incidence of nausea and vomiting after surgery in female adults compared to male adults. ${ }^{[2]}$ The incidence of PONV after day care and laparoscopic surgeries varies from $36-82 \%$ during immediate postoperative recovery and can be as high as $73 \%$ in certain gynecological procedures ${ }^{[3]}$.

There are multiple contributing factors that stimulate the vomiting reflex in PONV, yet no single component is typically the causative factor. The anesthesia related factors associated with emesis included premedication, inhalational agents, opioids, postoperative pain, patient mobilization, hemodynamic instability and initiation of oral intake. ${ }^{[4]}$ Many different antiemetic drugs are available for treatment of PONV. Balanced antiemesis, using drug combinations with different mechanisms and site of action is a better and worthwhile approach than single drug therapy. ${ }^{[5,6]}$

The introduction of 5-hydroxytryptamine (5-HT3) receptor antagonist was a major advancement in the treatment of postoperative nausea and vomiting because of the less adverse effects that were observed than commonly used traditional antiemetics ${ }^{[7]}$. Ondansetron is selective 5 -HT3 receptor antagonist possess property of superior antiemetic prophylaxis and is widely used for treatment of postoperative nausea and vomiting ${ }^{[8,9]}$. Granisetron a newer 5-HT3 antagonist has stronger receptor binding and has been found to be more potent and longer acting than ondansetron as antiemetic in chemotherapy and also for preventing postoperative nausea and vomiting following laparoscopic surgeries ${ }^{[9]}$. 


\begin{tabular}{|c|c|}
\hline & Consequences of PONV \\
\hline $\begin{array}{l}\text { Factors } \\
\text { Patient (physical) }\end{array}$ & $\begin{array}{l}\text { Consequences } \\
\text { Sweating, pallor, tachycardia, stomach aches, increased swallowing, electrolyte } \\
\text { disturbances }\end{array}$ \\
\hline Patient (surgical) & $\begin{array}{l}\text { Esophageal tears, wound dehiscence, disuption of vascular apostomegia. } \\
\text { increased intracranial pressure }\end{array}$ \\
\hline Patient (anesthesia) & Aspiration pneumonia \\
\hline Hospital & $\begin{array}{l}\text { Increased nursing care time, delayed discharge from Phases I and II, unexpected } \\
\text { admission, supplies, and antiemetic agents }\end{array}$ \\
\hline
\end{tabular}

The present study was undertaken to comparatively evaluate the efficacy of 5- $\mathrm{HT}_{3}$ antagonists Ondansetron and Granisetron for the prevention of PONV in female patients undergoing laparoscopic cholecystectomy

\section{Patients And Methods}

This prospective randomized double blind study included 100 female patients aged 15 - 60 years, belonging to ASA I class, undergoing laparoscopic cholecystectomy under general anaesthesia. A proper approval from the local ethics committee and informed consent was taken from the patients included in the study. In the preoperative holding area, patients were randomly allocated into two groups of 50 patients each and received study medications prepared by a single person in identical $5 \mathrm{ml}$ syringe and all study medications were diluted upto $5 \mathrm{ml}$ in $0.9 \%$ saline in order to ensure blinding.

Group X patients received $0.1 \mathrm{mg} / \mathrm{Kg}$ of ondansetron diluted to $5 \mathrm{ml}$ in $0.9 \%$ saline. (Ondansetron group)

Group Y patients received $0.04 \mathrm{mg} / \mathrm{Kgs}$ of Granisetron diluted to $5 \mathrm{ml}$ in $0.9 \%$ saline. (Granisetron group)

Following patients were excluded from the study:

1) Patients with history of motion sickness, migraine, or any other neurological problems.

2) Patients with history of postoperative nausea and vomiting during a previous surgery.

3) Patients who received antiemetics 48 hours prior to surgery.

4) Pregnant/lactating females.

In the operating room, after establishing an intravenous line, the study medication was administered one minute prior to induction of anaesthesia. Anaesthesia was induced with $5 \mathrm{mg} / \mathrm{kg}$ of $2.5 \%$ thiopentone sodium, atracurium $0.5 \mathrm{mg} / \mathrm{kg}$ and morphine $100 \mu \mathrm{g} / \mathrm{kg}$ followed by maintenance with nitrous oxide $66 \%$ in oxygen and supplemented with $0.5-1 \%$ halothane and atracurium $100 \mu \mathrm{g} / \mathrm{kg}$ based on neuromuscular monitoring done by train of four stimulation.

After tracheal intubation, a nasogastric tube was placed to promote baseline empting of stomach of air and gastric contents, which was removed at the end of surgery before tracheal extubation. During surgery, patients were positioned in the reverse Trendelenberg position with the right side of the table elevated. The abdomen was insufflated with $\mathrm{CO}_{2}$, to an intraabdominal pressure of $10-14 \mathrm{~mm} \mathrm{Hg}$. Intraoperative monitoring included ECG, pulse oximetry, non invasive blood pressure monitoring, which recorded systolic, diastolic and mean arterial blood pressure every 5 minutes. Duration of anaesthesia, surgery and $\mathrm{CO}_{2}$ insufflation were also recorded in each patient. Paracetamol $15 \mathrm{mg} / \mathrm{Kg}$ i/v was given towards the end of surgery. At the end of surgery neuromuscular block was reversed with neostigmine and glycopyrrolium.

After surgery patients were observed for a period of 24 hours by the same anaesthetist. Diclofenac sodium $75 \mathrm{mg} \mathrm{i} / \mathrm{m}$ was used as a rescue analgesic if patient complained of pain and requested for analgesia. The incidence of nausea and vomiting was recorded every 6 hourly for a period of 24 hours. No distinction was made between vomiting and retching (retching event was considered as vomiting event).

Nausea and vomiting was evaluated on a three point scale.

$0=$ none

$1=$ nausea

$2=$ vomiting

Rescue antiemetic medication was given in the form of injection (Ondansetron $0.1 \mathrm{mg} / \mathrm{kg}$ body weight) and repeated if the patient experienced severe nausea or if there were more than 3 emetic episodes with in a period of 15 minutes or if patient asked for it.

Pain intensity was assessed using a $10 \mathrm{~cm}$ visual analogue (VAS $0=$ no pain to $10=$ severe pain). Pain intensity was classified into 3 categories for easy statistical analysis. Severe if VAS score $>7$, moderate if VAS score $3-7$, mild if VAS score $<3$. Data collected was statistically evaluated and analyzed. Parametric data was 
expressed as mean $\pm \mathrm{SD}$, thereby the inter group comparisons were made by student's t-test . The test was two sided and referred for $p$-value for its significance. P-value less than $0.05(p<0.05)$ was taken to be statistically significant. The analysis was performed on SSPS version 11.3, statistical software for social sciences, Chicago, U.S.A for windows.

\section{Results}

There was no statistical difference between the two groups with regards to age, weight, duration of surgery and anaesthesia, duration of CO2 insufflation (TABLE 1). The variation of VAS score between the two groups at 1 and 2 hours was statistically insignificant ( $\mathrm{p}=0.245$ and 0.269 respectively). The variation in VAS score at 3, $4 \& 24$ hours was again statistically insignificant. No patient experienced severe pain (score $>7)$ at any stage of time in both groups.(TABLE 2)

Table 1.Comparison of demographic data and other characteristic in two groups

\begin{tabular}{|c|c|c|c|c|}
\hline Characteristics & Group X mean \pm SD & Group Y mean \pm SD & p value & Remarks \\
\hline Age (years) & $32.5 \pm 11.5$ & $29.3 \pm 10.2$ & 0.134 & NS \\
\hline Weight (Kgs) & $55.2 \pm 8.4$ & $54.6 \pm 9.4$ & 0.754 & NS \\
\hline Duration of Angesthesia in minutes & $68 \pm 8.8$ & $70.4 \pm 10.8$ & 0.22 & NS \\
\hline Duration of Surgery in minutes & $61.5 \pm 8.4$ & $63.9 \pm 11.2$ & 0.217 & NS \\
\hline $\begin{array}{c}\text { Duration of CO2 insufflation } \\
\text { in minutes }\end{array}$ & $56.74 \pm 8.1$ & $59.3 \pm 10.7$ & 0.18 & $\mathrm{NS}$ \\
\hline
\end{tabular}

\begin{tabular}{|c|c|c|c|c|}
\hline VAS score (Time) & $\begin{array}{c}\text { Group X } \\
\text { mean } \pm \text { SD }\end{array}$ & $\begin{array}{c}\text { Group Y } \\
\text { mean }+ \text { SD }\end{array}$ & pvalue & Remarlss \\
\hline 1 hour & $3.40=1.89$ & $3.77 \pm 2.16$ & 0.245 & NS \\
\hline 2 hour & $3.37 \pm 1.19$ & $3.77 \pm 1.17$ & 0.269 & NS \\
\hline 3 hour & $3.63=0.85$ & $3.57 \pm 0.68$ & 0.227 & NS \\
\hline 4 hour & $3.03=0.92$ & $2.90=0.61$ & 0.135 & Ns \\
\hline 24 hour & $2.33 \pm 0.61$ & $2.27 \pm 0.45$ & 0.582 & NS \\
\hline
\end{tabular}

In Group X (Ondansetron group), a complete response (PONV score 0) was observed in 34 patients (68\%) during $0-6$ hours after anaesthesia, whereas during further study intervals, complete response was seen in lesser number of patients, with score 0 in only 24 patients $(48 \%)$ at 24 hours post operatively. Similarly during $0-6$ hours of study 11 patients $(22 \%)$ had nausea (PONV score 1 ) where as 5 patients $(10 \%)$ had vomiting (PONV score 2), showing an overall incidence of emetic episode in 16 patients (32\%). The incidence of emetic episode increased further during next study intervals and was $56 \%$ at 24 hours post operatively (TABLE 3)

Table 3 : PONV scores at different time intervals in Group X

\begin{tabular}{|c|c|c|c|c|}
\hline \multirow[b]{2}{*}{ PONT score } & \multicolumn{4}{|c|}{ Time interval } \\
\hline & $\begin{array}{c}0-6 \text { hours } \\
\text { No. }(\%)\end{array}$ & $\begin{array}{c}6-12 \text { hours } \\
\text { No. }(\%)\end{array}$ & $\begin{array}{c}12 \text { - } 18 \text { hours } \\
\text { No. }(\%)\end{array}$ & $\begin{array}{c}18-24 \text { hours } \\
\text { No. }(\%)\end{array}$ \\
\hline$O$ (No nausea / vomiting) & $34(68)$ & $34(68)$ & $25(50)$ & $24(48)$ \\
\hline 1 (Nausea) & $11(22)$ & $10(20)$ & $23(46)$ & $20(40)$ \\
\hline 2 (Vomiting) & $5(10)$ & $6(12)$ & $2(4)$ & $8(16)$ \\
\hline Emetic episode & $16(32)$ & $16(32)$ & $25(50)$ & $28(56)$ \\
\hline
\end{tabular}

In group Y (Granisetron group), during $0-6$ hours after anaesthesia complete antiemetic response (PONV score 0 ) was observed in 41 patients $(82 \%)$ which during further study intervals remained more or less 
same, and at 24 hours postoperatively was seen in 40 patients (80\%). The overall incidence of emetic episode in group Y during $0-6$ hours of study was $18 \%$ with nausea (PONV score 1) seen in 7 patients (14\%) and vomiting (PONV score 2) only in 2 patient (4\%). At 24 hours after the surgery, the incidence of emetic episode was $20 \%$ with only 10 patients experiencing nausea and vomiting (TABLE 4).

Table 4: PONV scores at different time intervals in Group $Y$

\begin{tabular}{|c|c|c|c|c|}
\hline \multirow{2}{*}{ PONV Score } & \multicolumn{4}{|c|}{ Time interval } \\
\cline { 2 - 5 } & $\begin{array}{c}0-6 \text { hours } \\
\text { No. }(\%)\end{array}$ & $\begin{array}{c}6-12 \text { hours } \\
\text { No. }(\%)\end{array}$ & $\begin{array}{c}12-18 \text { hours } \\
\text { No. (\%) }\end{array}$ & $\begin{array}{c}18-24 \text { hours } \\
\text { No. (\%) }\end{array}$ \\
\hline O No nausea / vomiting) & $41(82)$ & $43(86)$ & $41(82)$ & $40(80)$ \\
\hline 1 (Nausea) & $7(14)$ & $3(6)$ & $6(12)$ & $7(14)$ \\
\hline 2 (Vomiting) & $2(4)$ & $4(8)$ & $3(6)$ & $3(6)$ \\
\hline Emetic episode & $9(18)$ & $7(14)$ & $9(18)$ & $10(20)$ \\
\hline
\end{tabular}

During $0-6$ hours after anaesthesia $9(18 \%)$ patients in group Y and $16(32 \%)$ patients in group X reported nausea and vomiting with insignificant variation, whereas at $6-12$ hours after anaesthesia, the variation in the incidence was significant $(\mathrm{p}=0.045)$ with $7(14 \%)$ patients in group $\mathrm{Y}$ reporting nausea and vomiting as compared to $16(32 \%)$ patients in group X. Similarly the incidence of nausea and vomiting was found to be highly significant between the groups during $12-18$ and $18-24$ hours, with $9(18 \%)$ and 10 (20\%) patients in group $\mathrm{Y}$ as compared to 25 ( $50 \%)$ and $28(56 \%)$ patients respectively in group $\mathrm{X}$ reporting nausea and vomiting during each time intervals (TABLE $5 \& 6$ ).

Table 5 - Comparison of incidence of nausea and vomiting between 2 groups at various time intervals during 24 hour studxperiod.

\begin{tabular}{|c|c|c|c|c|}
\hline Time interval & $\begin{array}{l}\text { Group X } \\
\text { No. }(\%)\end{array}$ & $\begin{array}{l}\text { Group Y } \\
\text { No. (\%) }\end{array}$ & pvalue & Remarks \\
\hline $\begin{array}{c}0-6 \text { hours } \\
\text { Nausea } \\
\text { Vomiting } \\
\text { Total }\end{array}$ & $\begin{array}{l}11(22) \\
5(10) \\
16(32)\end{array}$ & $\begin{array}{lr}7 & (14) \\
2 & (4) \\
9 & (18)\end{array}$ & 0.098 & NS \\
\hline $\begin{array}{c}6-12 \text { hours } \\
\text { Nausea } \\
\text { Vomiting } \\
\text { Total }\end{array}$ & $\begin{array}{l}10(20) \\
6(12) \\
16(32)\end{array}$ & $\begin{array}{lr}3 & (6) \\
4 & (8) \\
7 & (14)\end{array}$ & 0.045 & s \\
\hline $\begin{array}{c}12-18 \text { hours } \\
\text { Nausea } \\
\text { Vomiting } \\
\text { Total }\end{array}$ & $\begin{array}{l}23(46) \\
2 \quad(4) \\
25(50)\end{array}$ & $\begin{array}{lr}6 & (12) \\
3 & (6) \\
9 & (18)\end{array}$ & 0.002 & HS \\
\hline $\begin{array}{c}18-24 \text { hours } \\
\text { Nausea } \\
\text { Vomiting } \\
\text { Total }\end{array}$ & $\begin{array}{l}20(40) \\
6(12) \\
26(52)\end{array}$ & $\begin{array}{lr}7 & (14) \\
3 & (6) \\
10 & (20)\end{array}$ & 0.001 & HS \\
\hline
\end{tabular}

NS - Non Significant, S - Significant, HS - Highly Significant

Table 6: Comparison of incidence of PONV during 0-24 hours between 2 group

\begin{tabular}{|c|c|c|c|c|}
\hline \multirow{2}{*}{ Group } & \multicolumn{2}{|c|}{ PONV } & p value & Remarks \\
\cline { 2 - 3 } & $\begin{array}{c}\text { Yes } \\
\text { Number (\%) }\end{array}$ & $\begin{array}{c}\text { No } \\
\text { Number }(\%)\end{array}$ & & \\
\hline $\mathrm{X}$ & $26(52)$ & $24(48)$ & \multirow{2}{*}{$<0.001$} & Highly Significant \\
\hline $\mathrm{Y}$ & $10(20)$ & $40(80)$ & & \\
\hline
\end{tabular}

In group X 15 patients (30\%) asked for rescue anti-emetic where as in group $\mathrm{Y}$ only 2 patients (4\%) respectively required rescue anti-emetic. Requirement for rescue antiemetic medication in the two groups showed a statistically highly significant difference $(\mathrm{p}<0.001)($ TABLE 7$)$ 


\begin{tabular}{|c|c|c|c|c|}
\hline \multirow{3}{*}{ Group } & \multicolumn{2}{|c|}{ Rescue Antiemetic } & p value & Remarks \\
\cline { 2 - 3 } & $\begin{array}{c}\text { Used } \\
\text { No. }(\%)\end{array}$ & $\begin{array}{c}\text { Not Used } \\
\text { No. }(\%)\end{array}$ & & \multirow{2}{*}{$<0.001$} \\
\hline $\mathrm{X}$ & $15(30)$ & $35(70)$ & Highly Significant \\
\hline $\mathrm{Y}$ & $2(4)$ & $48(96)$ & & \\
\hline
\end{tabular}

\section{Discussion}

Post operative nausea and vomiting (PONV) are considered as very unpleasant side effects of anaesthesia, causing distress and dissatisfaction to patients. It is multifactorial and despite advances in antiemetic therapy the incidence is high. The main patient related factors are age, gender, history of motion sickness, previous post operative nausea and vomiting and pregnancy. The management of post operative nausea and vomiting is based primarily on treatment rather than prevention.

The three most common causes of admission following day care surgery are pain bleeding and vomiting ${ }^{[11]}$. Females are associated with higher incidence of PONV than males ${ }^{[2,11,13]}$ and may on average suffer three times more than males ${ }^{[12]}$. Women are more sensitive to emetic stimuli. The mechanism of post operative nausea and vomiting in them is complicated by prevailing hormone status. ${ }^{[8]}$

After laparoscopic cholecystectomy its incidence has been reported to be as high as 40-70\%. Naguib et al ${ }^{[14]}$ demonstrated that the incidence of PONV after laparoscopic surgeries in the placebo group was remarkably high $(72 \%)$. In our study the factors that would have contributed to nausea and vomiting may be laparoscopic surgery, use of halothane, morphine, nitrous etc.

We conducted study on 100 ASA I patients with demographic data in terms of age, weight, which were similar in the two groups. There was no significant difference in the Ondansetron and Granisetron Groups ( $p$ $<0.05$ ) in terms of age and weight. Study done by Paxton ${ }^{[15]}$ showed that PONV is more common in young age group and obese patients.

The quest for effective antiemetic drug without the potential for sedation, or extrapyramidal symptoms and other side effects lead to development of $5 \mathrm{HT}_{3}$ receptor antagonists i.e. Ondansetron, Granisetron, Topisetron, Palmosetron etc. Recently drug combinations with different mechanism and site of action have been used to achieve enhanced anti-emesis against PONV.

Our study shows no statistical significant difference in the baseline values of hemodynamic variables between the two groups, before during or after giving the study drugs. In PACU we recorded the SBP, DBP and $\mathrm{HR}$ at regular intervals. No hemodynamic alterations between the results were observed. The study by Dev ${ }^{[16]}$ also showed the same results.

In our study, a complete response (no nausea and vomiting) was observed in $80 \%$ patients in Granisetron group as compared to $48 \%$ in Ondansetron group, the difference was statistically highly significant. A statistically highly significant reduction $(\mathrm{p}<0.001)$ in the incidence of PONV was observed in Group Y when compared with Group X after the 12 hours of surgery. Only 4\% of patients in Group Y required rescue antiemetic medication as compared to $30 \%$ in Group X which was statistically highly significant.

According to Raphael ${ }^{[17]}$ optimal dose of Ondansetron for preventing post operative nausea and vomiting is $4 \mathrm{mg}$ and half life is 3 hours. While optimal dose of Granisetron is $2 \mathrm{mg}$ and half life is $8-9$ hours. So it is concluded that after 6 hours granisetron is more effective than ondansetron for preventing PONV. Present study showed that Granisetron is better than Ondansetron for preventing PONV. Bhattacharya ${ }^{[18]}$ in his study showed same results. Mikawa $\mathrm{K}$ et al ${ }^{[20]}$ reported the elimination half life of granisetron is 9 hours which is 2.5 hours longer than ondansetron, so it requires less frequent dosing which is in agreement with our study as shown be the usage of more rescue antiemetics in ondansetron group as compared with the granisetron group. Janknegt [19] studied that if ondansetron is given at induction time, it is ineffective in preventing PONV, so we administered study drug half an hour before end of surgery. This makes the drug to be more effective postoperatively for longer time.

Our results are in congruence with the study of B.B.Kushwaha et al ${ }^{[23]}$ who concluded that the incidence of PONV were maximum in the first 6 hours but granisetron showed higher incidence during 12-18 hours, whereas ondansetron showed higher incidence during the late postoperative period.

Y.Fujii et al ${ }^{[22]}$ reported that the effective dose of oral granisetron for prophylaxis of prevention of postoperative nausea and vomiting after laparoscopic cholecystectomy, the incidence of emesis free period was $60 \%$ with granisetron $1 \mathrm{mg}, 83 \%$ with $2 \mathrm{mg}$ and $83 \%$ with $4 \mathrm{mg}$ granisetron dose $(\mathrm{p}<0.01)$ compared with placebo 53\%. Preoperatively oral granisetron dose higher than $2 \mathrm{mg}$ was effective for prevention of 
postoperative nausea and vomiting after laparoscopic cholecystectomy. It is comparable with our study where our efficacy was $80 \%$ with granisetron using a dose of $0.04 \mathrm{mg} / \mathrm{Kg}$.

Incidence of Headache was $18 \%$ in Ondansetron group while it was $11 \%$ in Granisetron group showing a statistically significant difference $(\mathrm{p}<0.05)$. According to a study by Mitra ${ }^{[21]}$, the incidence of headache and constipation is more in the ondansetron than granisetron group which matches with our results. Incidence of constipation and dizziness were not significant on comparison between the 2 groups $\mathrm{X} \& \mathrm{Y}$.

\section{Conclusion}

In conclusion prophylactic administration of Granisetron is more effective than Ondansetron when used alone in reducing the incidence of PONV with prolonged effects.

\section{References}

[1] Watcha MF, White PF: post operative nausea and vomiting. Anesthesiology 1992; 77(1): $162-84$

[2] Fuji Y, Tanaka H, Toyooka H: The effect of Dexamethasone on antiemetics in female patients underling gynaecological surgery. Anesthesia Analgesia 1997; 85: 913 - 917

[3] Diemunsch P, Schoeffler P, Bryssine B: Antiemetic activity of the NK1 Receptor antagonist in the treatment of established post operative nausea and vomiting after major gynecological surgery. British Journal of Anaesthesia 1999; 82:274 - 276.

[4] Yogendran S, Sunthera LY: A prospective randomized double blinded study of the effect of intravenous fluid therapy on adverse outcomes in outpatient surfer. Anesthesia Analgesia 1995; 80:682 - 686

[5] Trammer R: A rational approach to control of post operative nausea and vomiting; evidence for prevention and treatment and research agenda. Acta Anesthesiologica Scand 2001; $45: 14$.

[6] Willium M, Splinter MD: Prevention of vomiting after strabismus surgery in children; Dexamethasone alone v/s Dexamethasone plus low dose Ondansetron. Pediatric Anesthesia 2001:11(5):591

[7] Bune KT, Tyres MB. The role of 5-HT in postoperative nausea and vomiting. British Journal of Anaesthesiology 1992; 69:245-325.

[8] Linbald T, Bucklers DN, Forrest JB: The incidence of post operative nausea and vomiting in women undergoing laparoscopy is influenced by the day of menstrual cycle. Canadian Journal of Anesthesia 1991; 38:298.

[9] Perez EA, Hesketh P, SandbackA J, Reeves J,Chawla S et al. Comparison of single dose oral Granisetron versus intravenous ondansetron in the prevention of nausea and vomiting induced by moderately emetogenic chemotherapy: A multicentric double blind randomized parallel study. J Clin Oncol 1998; 16(2): 754-760.

[10] Rajeeva V, Bhardwaj N, Batra YK, Dhaliwal LK: Comparison of Ondansetron with Ondansetron and dexamethasone in prevention of post operative nausea and vomiting in diagnostic laparoscopy Canadian Journal of Anesthesia 1999; 46 : 40 - 44.

[11] Gold BS, Kitz DS, Lecky JH. Unanticipated admission to the hospital following ambulatory surgery. JAMA 1989; 262:3008-10.

[12] Bonder M, Honkovaara P. Nausea and vomiting after gynaecological laparoscopy depends upon the phase of the menstrual cycle. Can J Anaesthesia 1991; 38: 876-87.

[13] Burtles R, Peckett BW: Postoperative vomiting; some factors affecting its incidence. British Journal of Anaesthesia 1957; 29: 114 123.

[14] Naguib M , E I Bakry AK, Khoshi MHB et al. Prophylactic antiemetic therapy with ondansetron, tropisetron, granisetron and metoclopramide in patients undergoing cholecystectomy. Can J Anaesthesia 1996; 43: 226-31.

[15] Paxton DL, McKay CA. Prevention of nausea vomiting after day care gynaecological laparoscopy. Anaesthesia 1995; 50: $403-46$.

[16] Dev N, Mehrotra S, Tyagi SK. A comparative study of ondansetron and metoclopramide. Indian Journal of Anaesthesia 1998; 42: 5256.

[17] Raphael JH, Norton AC. Antiemetic efficacy of prophylactic Ondansetron in laparoscopic surgery. Randomized double blind comparison with metoclopramide. British Journal of Anaesthesia 1993; 71: 845-48.

[18] Bhattcharya D, Banerjee A. Comparison of Ondansetron and Granisetron for prevention of nausea and vomiting following day care gynaecological laparoscopy. Indian Journal of Anesthesia 2003; 47: 279-82.

[19] Janknegt R. Clinical efficacy of antiemetic following surgery. Anaesthesia 1999; 54: 1054-68.

[20] Mikawa K, Tokayo Y, Nishina K et al. The antiemetic efficacy of prophylactic granisetron in gynaecologic surgery. Anaesth Analg 1995; 80: 970-974.

[21] Mitra S, Sharma S, Tak V. Prophylactic antiemetic for laparoscopic cholecystectomy; Ondansetron versus metoclopramide. Indian Journal of Anaesthesia 1999; 35:4

[22] Fujii Y, Tanaka H, Kawasaki T. Prophylaxis With Oral Granisetron for the Prevention of Nausea and Vomiting After Laparoscopic Cholecystectomy Prospective Randomized Study Arch Surg. 2001;136(1):101-104

[23] Kushwaha BB, Chakraborty A, Agarwal J, Malick A, Bhushan S, Bhattacharya P .Comparative study of granisetron and ondansetron alone and their combination with dexamethasone, for prevention of PONV in middle ear surgery. The internet journal of anesthesiology 2007 Volume-13 Number-2 